\title{
The Start and Stop Characteristics of a Pendulum Anemometer
}

\author{
by \\ M. Sanuki, S. Kimura and M. Baba \\ University of Tokyo
}

(Received August 27, 1958)

\begin{abstract}
The start and stop characteristics of a pendulum anemometer devised by the Swiss meteorologist $H$. Wrid are experimented in wind tunnel and free air. The anemometer is at present in use for the routine meteorological observation in the People's Republic of China, being simple and robust in spite of some shortcomings discussed in the present paper.
\end{abstract}

\section{Introduction}

One of the present writers had a chance during his visit to the People's Republic of China in 1957 to discuss the performance of the pendulum anemometer used for the routine meteorological observation in that country. The anemometer was devised by the Swiss meteorologist H. WILD in 1861 and has been a favourite tool of amateur observers and weather stations not equipped otherwise. The Weather Bureau of People's Republic of China introduced this type in view of its extreme simplicity of handling when they decided to expand their meteorological network into the present admirable scale. Some Chinese technical men, however, are keen enough to know its shortcomings which might exist. We have therefore conducted the present experiment, not in the spirit of criticism, but to offer possible collaboration with our colleagues on the continent.

\section{Experimental set-up}

A brass plate of $150 \mathrm{~mm}$ in width, $300 \mathrm{~mm}$ in length and $0.7 \mathrm{~mm}$ in thickness is hinged along the width as shown in Fig. 1. The original anemometer of WiLD had exactly the same width and length but different thickness of about $0.57 \mathrm{~mm}$ when the plate is of steel. The difference of thickness and material is counterbalanced by incorporating nine perforations as illustrated in Fig. 1 and the same weight of $200 \mathrm{gr}$ is attained in both cases. The perforations can readily be covered with plastic tapes of negligible weight, and, if not, the aerodynamic contribution of the presence of perforations is of some interest to us.

Around one support of the hinge axis a circular resistor ring is attached on 

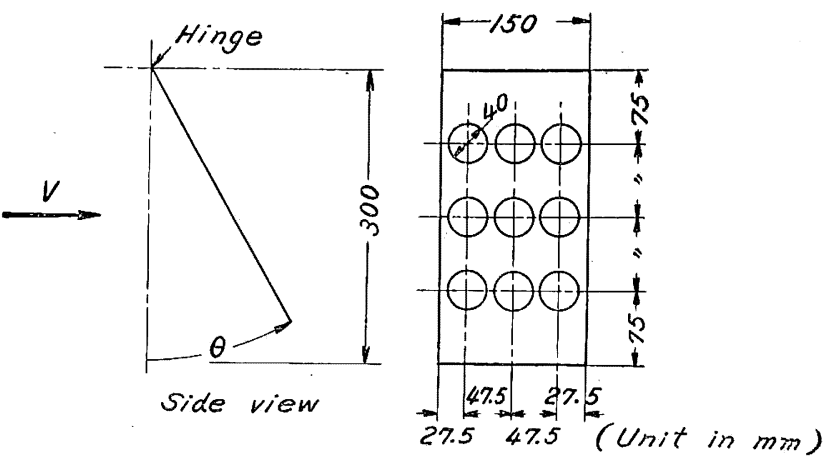

Material, brass

Thickness, $0.7 \mathrm{~mm}$

Weight, $200 g^{\prime}$

Fig. 1 Experimented pendulum anemometer with perforations which can be covered with plastic tapes.

which a sliding pointer of the anemometer rotates to obtain the angular position. The record is obtained by means of an electromagnetic oscillograph.

In the wind tunnel the anemometer is first held vertical with wind on and then let free to perform the transient oscillation until it shows a steady deflection corresponding to the wind speed. The steady defection angle is calibrated beforehand against wind speed $V$ as shown in Fig. 2. The experiment is carried out in the wind tunnel of $1.5 \mathrm{~m}$ diameter of the Meteorological Research Institute.

The stop characteristics of the anemometer is experimented in the free air of the laboratory to perform a damped oscillation from a certain deflection angle corresponding to a wind speed.

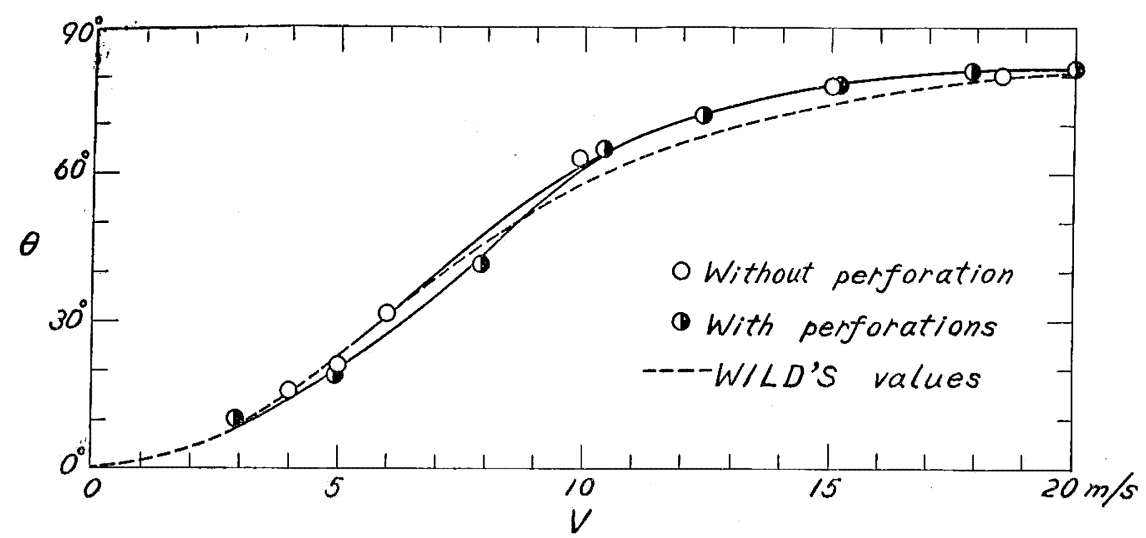

Fig. 2 Deflection angle of the pendulum anemometer from the vertical, versus wind speed (M. R. I. wind tunnel). 


\section{Discussion of the results}

The transient oscillation or the starting characteristics are jllustrated in Fig. 3, in which the deflection angle $\theta$ from the vertical is drawn against time $t$.

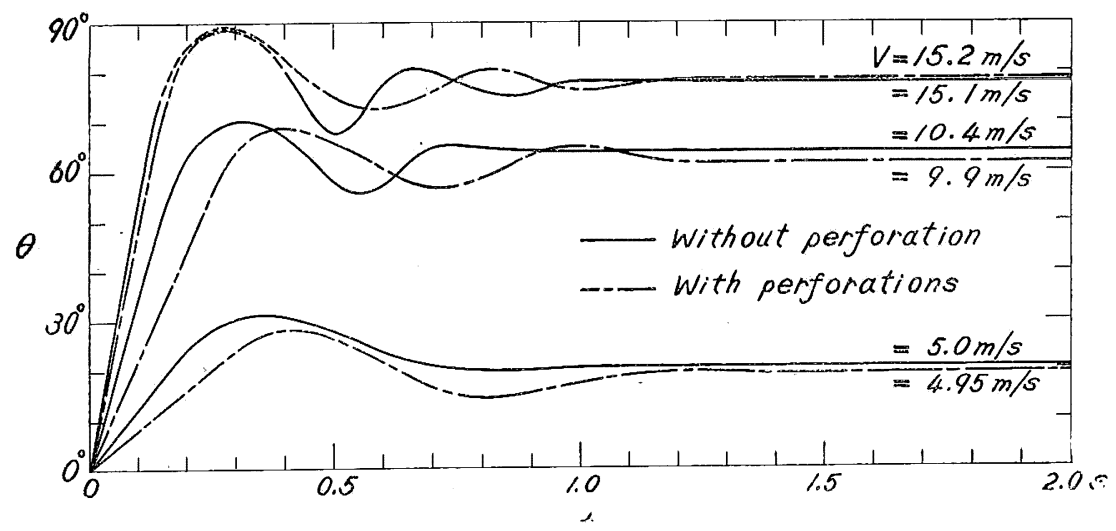

Fig. 3 Starting characteristics of the pendulum anemometer (M. R. I. wind tunnel).

In case of the anemometer without perforations the steady state deflection is reached within ca. $1 / 5 \mathrm{~s}$, after which, however, a certain amount of overshooting, 50 to $10 \%$ of the steady value, decreasing with increasing wind speed, can be observed. The final steady state is reached after about $1 \mathrm{~s}$ irrespective of the wind speed. These transient characteristics are rather superior to those of a cup anemometer which attains its steady indication only after a few seconds, or even to a Dines pressure tube which is never a better counterpart of the cup anemometer.

The presence of perforations contribute nothing to the starting characteristics of the anemometer, lagging the start by about $2 / 3 \mathrm{~s}$ for lower wind speed.

The stop characteristics or the free oscillation of the anemometer are illustrated in Fig. 4.

The free oscillation continues up to

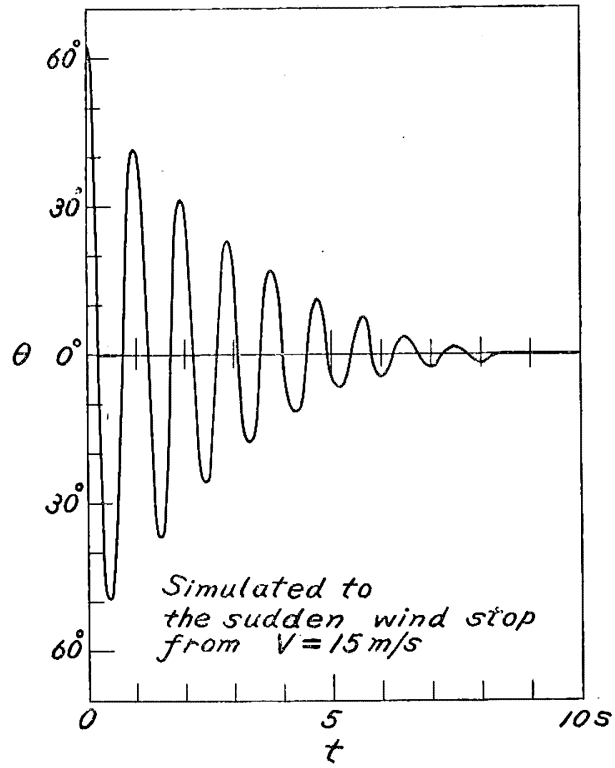

Fig. 4 Free oscillation of the pendulum anemometer without perforations

(almost similar in mode to that with perforations). 
about 8 to $9 \mathrm{~s}$ except for simulated lower wind speeds than $5 \mathrm{~m} / \mathrm{s}$. These characteristics are again never inferior to those of the cup anemometer or Dines pressure tube for which zero indication necessitates tens of seconds after sudden wind stop. The period of the free oscillation of the present anemometer is precisely $0.95 \mathrm{~s}$ irrespective of the initial deflection angle, and the time constant is from 2 to $3 \mathrm{~s}$. The perforations have nothing to do with the stop characteristics.

The calibration of deflection angle as illustrated in Fig. 2 shows a reasonable coincidence with that of WILD [Reference] except for higher wind speeds, which region suffers at the same time from lack of sensitivity of indication. The sensitivity is also poor for wind speeds lower than $3 \mathrm{~m} / \mathrm{s}$.

The real shortcomings of the pendulum anemometer consist in these low sensitivity especially for higher wind speeds, say, over $15 \mathrm{~m} / \mathrm{s}$, and the uncertainty of reading unless some remote-reading facilities such as the present experimental setup are employed.

\section{Conclusions}

1) The transient characteristics of the pendulum anemometer are not inferior, but even superior to the conventional cup anemometer or Dines pressure tube.

2) The calibration of indication must be exact corresponding to the actual state.

3) The sensitivity is poor for low and high wind speed regions.

4) For accurate reading some remote-reading facilities must be employed.

5) Perforations, if any, have nothing to do with the improvement of aerodynamic characteristics of the pendulum anemometer.

Acknowledgements The writers are indebted to the chance tendered by the Central Weather Bureau of the People's Republic of China led by Prof. Tu CHANG-WANG, to one of the writers to visit that country. Despite the political difflculties prevailing for the time being the writers hope the present paper will be accepted as a token of friendship.

\section{Reference}

E. Kleinsohmidt, 1935: Handbuch der meteorologischen Instrumente (Julius Springer, Berlin), S. 364 .

平板風速計の始動及び停止特性

佐貫亦男，木村 茂，馬場素生

中華人民共和国で，気像業務観测飞使われているWILD 式平板（振子形）風速計の始動及び停止特性 を, 気象研究所 $1.5 \mathrm{~m}$ 風洞及び実鈳室内の静止大気中で実歌した。これら過没特性は從来の椀形及びダイ ンス風速計飞劣らず，むしろすぐれている結果が出た。平板風速計の欠点は， $15 \mathrm{~m} / \mathrm{s}$ 以上の高風速注対し

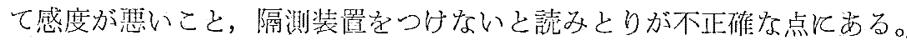

